\title{
Proliferation in the Rat Olfactory Epithelium: Age-Dependent Changes
}

\author{
Elke Weiler and Albert I. Farbman \\ Department of Neurobiology and Physiology, Northwestern University, Evanston, Illinois 60208-3520
}

\begin{abstract}
Vertebrate olfactory sensory neurons are replaced continuously throughout life. We studied the effect of age on proliferation in olfactory epithelium in postnatal rats ranging in age from birth (P1) until P333. Using BrdU to label dividing cells, we determined the proliferation density of basal cells, i.e., the number of labeled nuclei/unit length $(240 \mu \mathrm{m})$ of olfactory epithelium in coronal sections from six different anterior-posterior levels from each animal. A total length of $>1 \mathrm{~m}$ of olfactory epithelium was counted in each age group. We observed a dramatic decrease of proliferation density from $\mathrm{P} 1$ through $\mathrm{P} 333$. At P1, proliferation density is 151 cells $/ \mathrm{mm}$; it decreases to approximately half at P21 (70 cells $/ \mathrm{mm})$, and half again at P40 (37 cells $/ \mathrm{mm})$. At P333 the proliferation density was only $8 / \mathrm{mm}, \sim 5 \%$ of that seen at $\mathrm{P} 1$. The changes were clearly related to age and not to
\end{abstract}

body weight, because the values were essentially identical for males and females of the same age but of different body weight. Proliferating cells appear in patches that, after P40, become more separated from one another and contain fewer cells. In 6- and 11-month-old rats, 30 and $45 \%$ of all units contained no labeled cells. We confirmed the data of others that the olfactory surface area continuously increases with age; we showed that there is a reciprocal relationship between proliferation density and surface area. The proliferating cells provide neurons to sustain growth as well as to replace dying cells.

Key words: olfactory epithelium; proliferation density; basal cell; development; BrdU method; growth and replacement; turnover; mitosis; neurogenesis; age
Olfactory sensory neurons are replaced continuously throughout life in vertebrates. The uniqueness of the olfactory system lies in the fact that a progenitor population of globose basal cells (cf. Mackay-Sim and Kittel, 1991b; Schwartz Levey et al., 1991; Suzuki and Takeda, 1991) can divide and differentiate and, therefore, can reconstitute the sensory epithelium, even under physiological conditions (Moulton et al., 1970; Thornhill, 1970; Graziadei and Metcalf, 1971; for review, see Farbman, 1992). The average life span of olfactory neurons was thought to be $\sim 1$ month (Moulton, 1975; Graziadei and Monti Graziadei, 1979), although some evidence suggests they live considerably longer (Hinds et al., 1984; Mackay-Sim and Kittel, 1991a,b). In rodents, the life span varies from $\leq 24 \mathrm{hr}$ (Carr and Farbman, 1992) to $>1$ year (Hinds et al., 1984).

Neurogenesis has been studied primarily in the "wound-healing" model (after massive cell death is experimentally induced). After ablation of the olfactory bulb or axotomy of the olfactory nerve, there is an increase in proliferation density, i.e., the number of cells labeled with a DNA precursor/unit length or volume of epithelium (Schwartz Levey et al., 1991; Suzuki and Takeda, 1991; Carr and Farbman, 1992). Upregulation of the mitotic rate can also be induced by destroying the epithelium with zinc sulfate (Cancalon, 1982), methyl bromide (Schwob et al., 1995), or $N$-methyl-formimino-methylester (Rehn et al., 1981). In recovery, the mitotic rate is increased over control levels. On the other hand, the occlusion of one nostril in a newborn rat results in a downregulation of the proliferative rate on

Received Dec. 9, 1996; revised Feb. 13, 1997; accepted Feb. 24, 1997.

This work was supported by National Institutes of Health Grant DC 00347.

Correspondence should be addressed to Dr. Albert I. Farbman, Department of Neurobiology and Physiology, Northwestern University, 2153 North Campus Drive Evanston, IL 60208-3520.

Copyright (C) 1997 Society for Neuroscience $0270-6474 / 97 / 173610-13 \$ 05.00 / 0$ the side ipsilateral to the occlusion (Farbman et al., 1988; Cummings and Brunjes, 1994).

In all of these reports, the possible influence of age on proliferation density was virtually ignored. Smart (1971) was the first to note, in passing, that there "... appeared to be a progressive decrease in the frequency of mitosis with age ..." (up to postnatal day 58). In a direct examination of the influence of age on proliferation density in mice, Dodson and Bannister (1980) reported a lower index (tritiated thymidine-labeled cells/total cells) with age, but only three age groups were examined, $19 \mathrm{~d}, 6$ months, and 1.5 years. In other studies, the reported data revealed mitotic rate decreases in older control animals, but the authors either took no special note of it (Cummings and Brunjes, 1994; Holtmaat et al., 1995) or simply mentioned it in passing (Hinds et al., 1984; Paternostro and Meisami, 1994).

In the present study, we report that proliferation density in the olfactory epithelium of unperturbed rats declines dramatically with age (irrespective of body weight) from the neonate to the age of 11 months. Further, we argue that the data are consistent with the hypothesis that the life span of individual olfactory neurons increases with age.

\section{MATERIALS AND METHODS}

Animals. Sprague Dawley rats of both sexes were used at postnatal ages ranging from P1 (day of birth) to P333 (Table 1). They were bred in our colony and housed in a temperature-controlled environment with a $12 \mathrm{hr}$ light/dark cycle and access to food and water ad libitum. Newborns were allowed to suckle until day 40 (weaning). During that time, they were weighed every other day. After weaning, animals were separated by sex and kept in groups. From then on, they were weighed twice a week. Animals from different litters were used in each age group.

BrdU injection, perfusion, and fixation. To label dividing cells, animals were given a single dose $(50 \mathrm{mg} / \mathrm{kg}$ body weight) of BrdU (5-bromo-2'deoxyuridine, Sigma B 5002, St. Louis, MO) intraperitoneally in a solu- 


\begin{tabular}{|c|c|c|c|c|c|c|c|c|}
\hline Age & $\begin{array}{l}\mathrm{Nu} \\
\mathrm{m}\end{array}$ & $\underset{f}{\text { nimals }}$ & $\mathrm{N}$ & $\begin{array}{l}\text { Cells } \\
\text { per mm }\end{array}$ & SE & $\begin{array}{l}\text { Significance } \\
p \text { value* }\end{array}$ & $\begin{array}{l}\text { Counted } \\
\text { units }\end{array}$ & $\begin{array}{l}\text { Counted } \\
\mathrm{mm}\end{array}$ \\
\hline P1-3 & 2 & 2 & 4 & 150.88 & 4.51 & & 662 & 158.09 \\
\hline \multirow[t]{2}{*}{ P11 } & 0 & 1 & 1 & 118.65 & & & 415 & 99.10 \\
\hline & & & & & & $0.002^{* *}$ & & \\
\hline \multirow[t]{2}{*}{ P21 } & 4 & 2 & 6 & 69.85 & 2.19 & & 5075 & 1211.91 \\
\hline & & & & & & 0.0001 & & \\
\hline \multirow[t]{2}{*}{ P40 } & 4 & 5 & 9 & 36.81 & 3.04 & & 5340 & 1275.19 \\
\hline & & & & & & 0.0001 & & \\
\hline \multirow[t]{2}{*}{ P66 } & 3 & 4 & 7 & 24.24 & 1.44 & & 4264 & 1018.24 \\
\hline & & & & & & 0.001 & & \\
\hline \multirow[t]{2}{*}{ P105 } & 4 & 1 & 5 & 16.80 & 0.25 & & 4271 & 1019.91 \\
\hline & & & & & & 0.018 & & \\
\hline \multirow[t]{2}{*}{ P181 } & 3 & 0 & 3 & 10.16 & 0.76 & & 3912 & 934.19 \\
\hline & & & & & & 0.05 & & \\
\hline P333 & 3 & 0 & 3 & 8.03 & 0.24 & & 5093 & 1216.21 \\
\hline
\end{tabular}

$\mathrm{m}=$ males; $\mathrm{f}=$ females; $\mathrm{N}=$ total number of animals.

*Mann-Whitney $U$ test, $\mathrm{U}=0$ among all age groups; the values did not overlap between age groups, so that $p$ depends only on the number of animals.

**P1-3 and P11 were combined as one group for the calculation of the $p$ value.

tion of $20 \mathrm{mg} / \mathrm{ml} \mathrm{PBS,} \mathrm{pH} \mathrm{7.2.} \mathrm{The} \mathrm{injection} \mathrm{was} \mathrm{given} \mathrm{between} \mathrm{8:00} \mathrm{A.M.}$ and 10:00 A.M. One hour later, rats were killed by intraperitoneal injection of a lethal dose of sodium pentobarbital $(250 \mathrm{mg} / \mathrm{kg}$ body weight). While under deep anesthesia, the animals were perfused (with a perfusion pump) intracardially through the left ventricle with $0.1 \mathrm{M}$ PBS, $\mathrm{pH} 7.2$, at room temperature (RT) to clear the vessels of blood. The total flow of perfusate was $1 \mathrm{ml} / \mathrm{gm}$ body weight; the rate of flow was adjusted to take $5 \mathrm{~min}$. This was followed by perfusion of a fixative solution, $4 \%$ paraformaldehyde in $0.1 \mathrm{M}$ Sørensen's phosphate buffer, $\mathrm{pH} 7.0(1 \mathrm{ml} / \mathrm{gm}$ body weight, $20 \mathrm{~min}, \mathrm{RT}$ ). Heads were removed, skinned, and post-fixed overnight in the same fixative at $4^{\circ} \mathrm{C}$. After washing several times in $0.1 \mathrm{M}$ Sørensen's phosphate buffer, $\mathrm{pH} 7.0$, they were processed for histology.

Histology (decalcification, embedding, sectioning). As much of the bone as possible was removed before the noses were decalcified in 5\% EDTA in $0.1 \mathrm{M}$ Sørensen's phosphate buffer for several days, with daily changes of solution. After decalcification, the specimens were washed in distilled water, dehydrated in increasing concentrations of ethanol and transferred to Histosol (National Diagnostics, Atlanta, GA) to clear the tissue. The specimens were infiltrated with paraplast and embedded. Frontal (coronal) sections of $10 \mu \mathrm{m}$ were cut serially from the tip of the nose to the most posterior extension of the olfactory epithelium, and each section was preserved.

Staining. Every 10th section was placed on silane (3'-aminopropyltriethoxy-silane, Sigma A-3648) treated slides. Sections were deparaffinized, rehydrated to water, stained with hematoxylin and eosin (H\&E), dehydrated again, mounted permanently with Permount, and coverslipped. These sections were used to demonstrate the extent of the olfactory epithelium and to determine the regions (see below), as well as to measure the area and thickness of the epithelium and the cell density.

$B r d U$ immunohistochemistry. After $2 \mathrm{hr}$ of UV light activation (our unpublished results), sections were rehydrated and treated with trypsin $\left(0.1 \%\right.$ trypsin, Sigma T-8642, $0.1 \% \mathrm{CaCl}_{2}$ in $0.05 \mathrm{M}$ Tris buffer for $10 \mathrm{~min}$ at room temperature) to increase the signal of the antibody reaction (Hayashi et al., 1988) and washed afterward several times in PBS. Sections were then incubated sequentially at $37^{\circ} \mathrm{C}$ in a $1: 1$ mixture of normal horse serum and $0.1 \mathrm{M}$ PBS to block nonspecific binding (60 min), an antibody against $\mathrm{BrdU}$ [undiluted Amersham anti-bromlodeoxyuridine solution, containing mouse monoclonal antibody and a nuclease, Amersham RPN 202, Amersham Life Science, Arlington Heights, IL (60 min)], the Vectastain Elite Kit for mouse antibodies (Vector Labs, Burlingame, CA) containing biotinylated horse anti-mouse secondary antibody (30 $\mathrm{min})$ and the $\mathrm{ABC}$ reagent $(45 \mathrm{~min})$. Each antibody treatment was followed by a 15 min wash with PBS at room temperature. Specimens were then incubated for $5 \mathrm{~min}$ at room temperature in a freshly made solution containing $0.01 \%$ hydrogen peroxide and $0.05 \% 3,3^{\prime}$ diaminobenzidine in $0.1 \mathrm{M}$ Tris- $\mathrm{HCl}$ buffer, $\mathrm{pH} 7.5$, to reveal the BrdU immunoreactivity. To stop the reaction, specimens were placed in distilled water, washed several times, and dehydrated in increasing concentrations of ethanol before being mounted permanently with Permount and coverslipped.

Selection of sections. The sections used to determine the area of the olfactory sheet were taken from the H\&E stained series at equidistant intervals, appropriate for the age, from the entire anterior-posterior extent of the olfactory epithelium.

For measuring the thickness of the olfactory epithelium, the H\&Estained sections were used. To avoid artifactual thickness measurements at the edges, where the turbinates either are first visible in a section or are seen to fuse, only sections where the turbinate was fully developed were used for measurements. These sections were also used to determine the cell density.

The immunohistochemical procedure for determining the proliferation density was applied to sections from six different regions, ranging from anterior to posterior. Because the turbinates develop allometrically and not symmetrically, we used sections from the following regions defined by the pattern of the turbinates rather than sections at equidistant intervals (Fig. 1):

Region 1: Where the first appearance of the turbinates is located in the section (the dorsal part of the second endoturbinate, appears first).

Region 2: The first and second ectoturbinates as well as the second endoturbinate, are well represented and the third ectoturbinate just starts to appear.

Region 3: All turbinates are fully visible.

Region 4: The second endoturbinate fuses with the bone on the dorsal part of the nasal cavity.

Region 5: The third endoturbinate fuses with the bone of the dorsal part of the nasal cavity.

Region 6: The fourth endoturbinate fuses with the bone of the dorsal part of the nasal cavity.

These regions could be observed and defined in rats aged $\geq 40 \mathrm{~d}$. In 11and 21-d-old animals, region 3 was defined as the full appearance of all turbinates except the fourth, but before any turbinate fusion. In younger animals the regions could not be defined in this manner, because the turbinates are not as fully developed. In these cases, the first and last regions were determined and sections from intervening regions were taken at equidistant intervals, to give a total of six regions.

Measurements. For all measurements and counts except cell density, we used an ocular micrometer and a magnification of $400 \times$ or $1000 \times$. At these magnifications, each of the 100 units on the ocular micrometer scale represented 2.4 or $1.0 \mu \mathrm{m}$, respectively. Thus, in the BrdU study, we counted the number of BrdU-positive cells in a $240 \mu \mathrm{m}$ unit of epithelial length.

Area of the olfactory epithelium. To confirm that the areas of olfactory epithelium in our rats increased with age (Hinds and McNelly, 1981; 


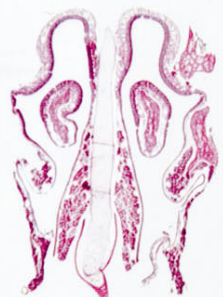

1

\section{$2 \mathrm{~mm}$}

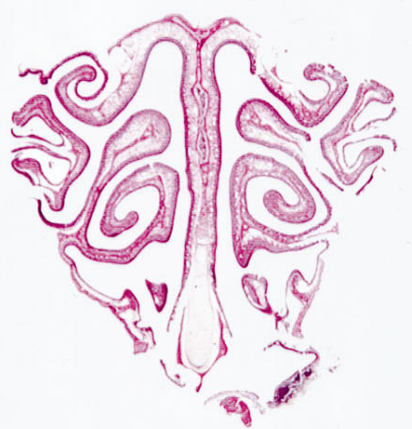

2

Figure 1. Coronal sections from the rat nose at different anterior-posterior levels. These six regions, defined by the pattern of the turbinates were used in the present study.

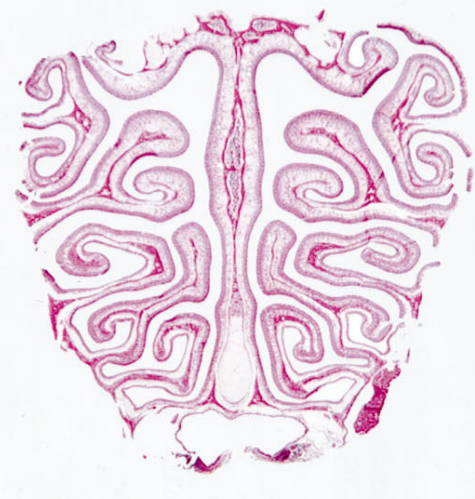

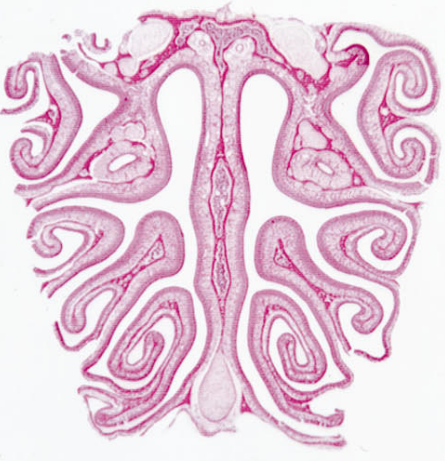

4

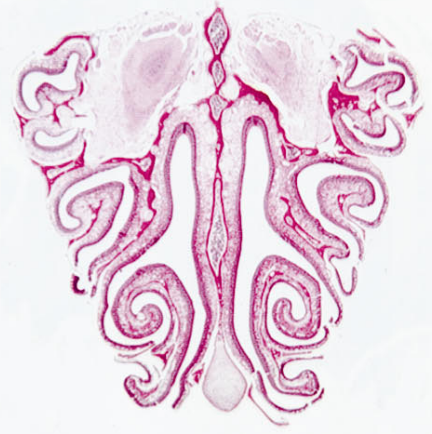

5

6

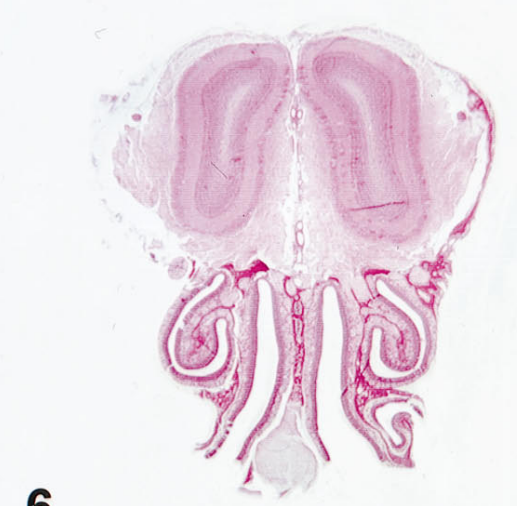

Meisami, 1989; Apfelbach et al., 1991; Paternostro and Meisami, 1993), we measured the area of the olfactory sheet on the right side in sections from one randomly selected male rat in each age group. By tracing along the olfactory epithelium of the H\&E-stained frontal sections, the epithelial length was measured at equidistant intervals along the anteriorposterior axis (for P1, every $200 \mu \mathrm{m}$; for P21 and P40; every $400 \mu \mathrm{m}$; for all others, every $500 \mu \mathrm{m}$ ). The measurements were graphed and the areas under the curves were calculated.

Epithelium thickness. The thickness of the olfactory epithelium was measured on the right side of H\&E sections adjacent to those on which the immunostaining was performed. The measurements were taken at $240 \mu \mathrm{m}$ intervals on each section all around the whole septum and turbinates. With this procedure, $\sim 100$ values per section were collected The measured thickness was from the basement membrane to the top of the knobs. The values of all measurements of the sections for each individual animal were averaged, and the mean value for the animals in each age group was calculated.

Cell density. To determine cell density, the number of nuclei in a 200 $\mu \mathrm{m}$ length of epithelium was counted with a computerized morphometric system, ANALYSIS, connected to a CCD camera on a Zeiss (Oberkochen, Germany) photomicroscope. (We are grateful to Dr. R. Apfelbach, University of Tübingen for permission to use this system.) The thickness of the epithelium of each sample was measured at the middle of the length, and the supporting cells, basal cells, and neurons were counted as separate populations. We used the position, staining pattern, and shape of the cell nucleus to discriminate the cell types. We realize that it is not always possible to discriminate between a very young neuron and a globose basal cell, but attempted to be consistent in applying our criteria to all specimens; thus, the counts of basal cells and neurons should be regarded as reasonable estimates. The number of basal cells 


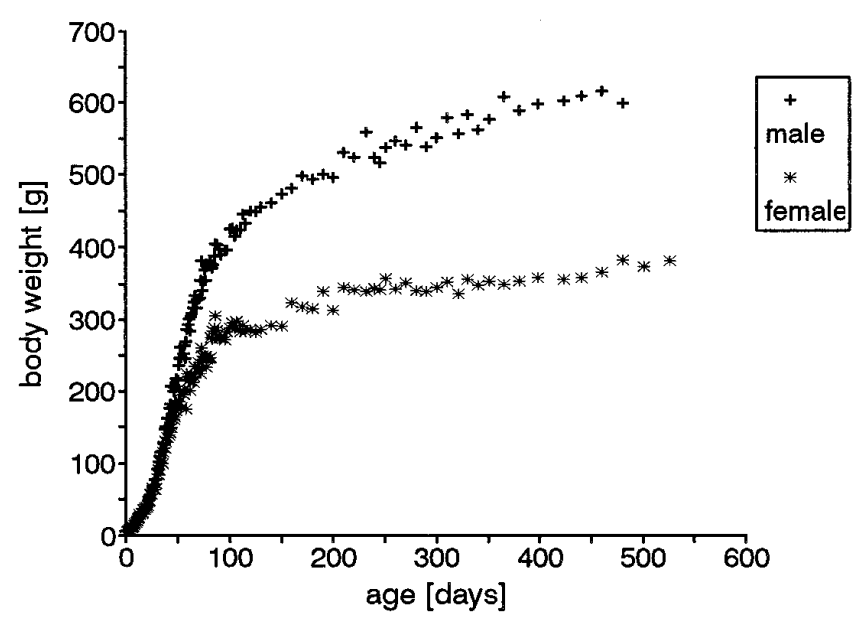

Figure 2. Postnatal changes in the mean value of the body weight from male and female Sprague Dawley rats. Body weight increase continues with age (during the period studied) in males as well as in females. The females show a significantly slower increase after P25 compared with males.

was estimated by counting the number of nuclei in the basalmost layer of epithelium, whether they were round or flat. The number of neurons was estimated by counting all suprabasal round nuclei in the epithelium, and the number of oval-shaped supporting cell nuclei in the most superficial nuclear layer was estimated. Repeat counts of selected specimens demonstrated that our method was reproducible. Approximately 16-17 samples were taken from the septum and turbinates in each animal. Samples were chosen randomly at different epithelial thicknesses. We had ascertained earlier that the nuclei of the neurons in the different age groups were the same size. We did not use a correction factor (Abercrombie, 1946; Coggeshall and Lekan, 1996), because there was little variation in nuclear size or section thickness. Another reason for not using correction factors was that in the counts of BrdU-positive cells, the stained nuclei appeared larger because the marker often spread beyond the nuclear margins and it was not possible to discriminate easily between a nucleus cut through its center or closer to its margin. Because we wanted to correlate the BrdU counts and the cell density counts, we could not correct one without the other.

Proliferation density. To determine the proliferation density, the numbers of BrdU-labeled basal cells were counted along $240 \mu \mathrm{m}$ length units of the olfactory epithelium over the whole section in each region. Except for the newborns, between 400 and 1200 units (between 100 and $300 \mathrm{~mm}$ of olfactory epithelium) for each animal were counted. Right and left sides were counted separately in each region, and the septum and turbinates of each region were counted separately. For each age group except the neonates, a total length of $\sim 1 \mathrm{~m}$ of olfactory epithelium was evaluated (Table 1).

Analysis of data. To analyze the proliferation density (number of labeled basal cells per unit length epithelium), several parameters were calculated.

For each animal the proliferation density of the different regions (anterior-posterior extent) as well as of the septum and the individual turbinates was averaged separately. Because there were no differences between values for septum and turbinates, these values were combined and averaged within each age group.

To obtain a mean value for the whole olfactory epithelium of an animal, all counted values were taken and averaged. These mean animal values were used to calculate the mean value of the age group.

In addition, the specimens were analyzed for the distribution pattern of the proliferating cells as follows. All values of the proliferation density per unit were ordered and the percent frequency for each density calculated for each animal. The distribution pattern was graphed for each animal. The mean values of the percent frequency were calculated for each density to give the distribution pattern of the age group.

For each animal, right and left side were measured and counted separately and compared.

The data for males and females were compared for each age group.

Statistics. We used the nonparametric Mann-Whitney $U$ test to deter-

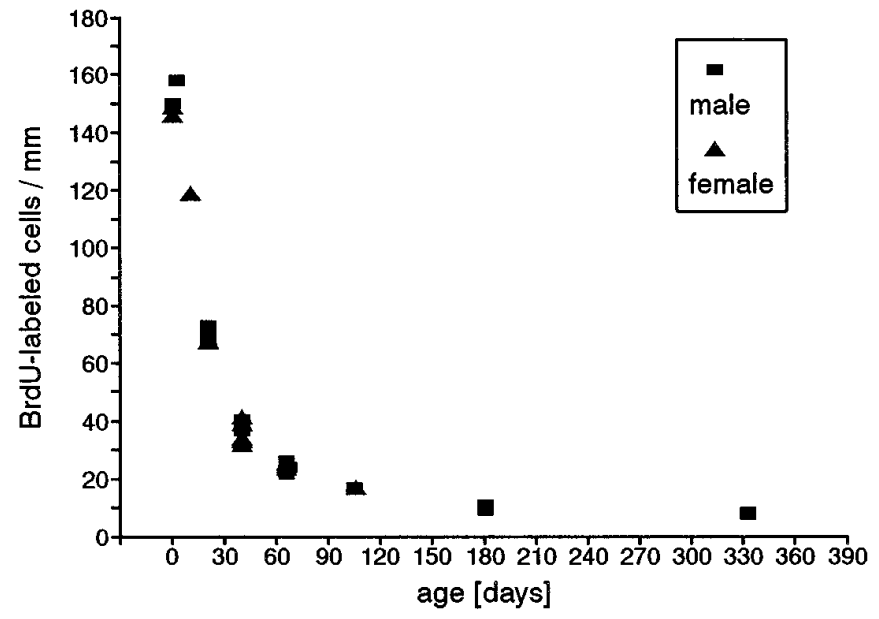

Figure 3. Proliferation density in the olfactory epithelium measured as the number of BrdU-labeled basal cells per millimeter. Each symbol represents the average value of one animal. In some age groups, the values are so close that they cannot be distinguished as separate symbols. For detail (animal numbers), see Table 1. The values for males and females at the same age are not different from one another.

mine whether there were differences in the cell and proliferation densities among age groups, as well as differences between the right versus left side, females versus males, and among the antero-posterior regions (Lienert, 1973). The epithelial thickness measurements were performed only on the right side, and the Mann-Whitney $U$ test was used to determine whether there were differences in thickness among groups. To analyze differences in the distribution pattern, we used the KolmogoroffSmirnoff test (Sachs, 1982).

\section{RESULTS}

\section{Age-dependent change in proliferation}

The body weight of rats continues to increase for most of their lives, until senescence (Fig. 2), and the total surface area covered by olfactory epithelium also increases (see below, Fig. 8; Hinds and McNelly 1981). In this part of the study, we examined the rate of proliferation as a function of age by injecting rats of different ages with BrdU and killing $1 \mathrm{hr}$ later.

Proliferation density in the olfactory epithelium, measured as the number of BrdU-labeled basal cells per millimeter length, showed a dramatic asymptotic decrease as the animals became older (Fig. 3, Table 1). In neonates, proliferation density was high, with an average value of 151 labeled cells $/ \mathrm{mm}$. At P21, the value decreased to approximately half this value $(70$ cells $/ \mathrm{mm})$, and to half again at P40 (37 cells $/ \mathrm{mm})$. It is important to note that the density still decreased in the adult (P66, 24 cells $/ \mathrm{mm})$, reaching values of only $\sim 10 \%$ of that of newborns at P105 (17 cells $/ \mathrm{mm}$ ). The proliferation density did not reach a plateau, but decreased again between 6 months $(10$ cells $/ \mathrm{mm})$ and 11 months, an additional reduction of $20 \%$ was observed, reaching only 8 cells $/ \mathrm{mm}$, half the value of that at P105. The differences in the proliferation densities among all age groups were highly significant (Table 1).

\section{Distribution pattern: dividing cells appear in clusters}

We ordered the data in terms of frequency of occurrence by plotting the number of labeled basal cells counted within each unit length of epithelium in a single microscopic field (each unit was $240 \mu \mathrm{m}$ long at $400 \times$ magnification). Figure 4 is a graph showing the distribution patterns for each age group. Along with the age-related decrease in proliferation density, there was a reduc- 

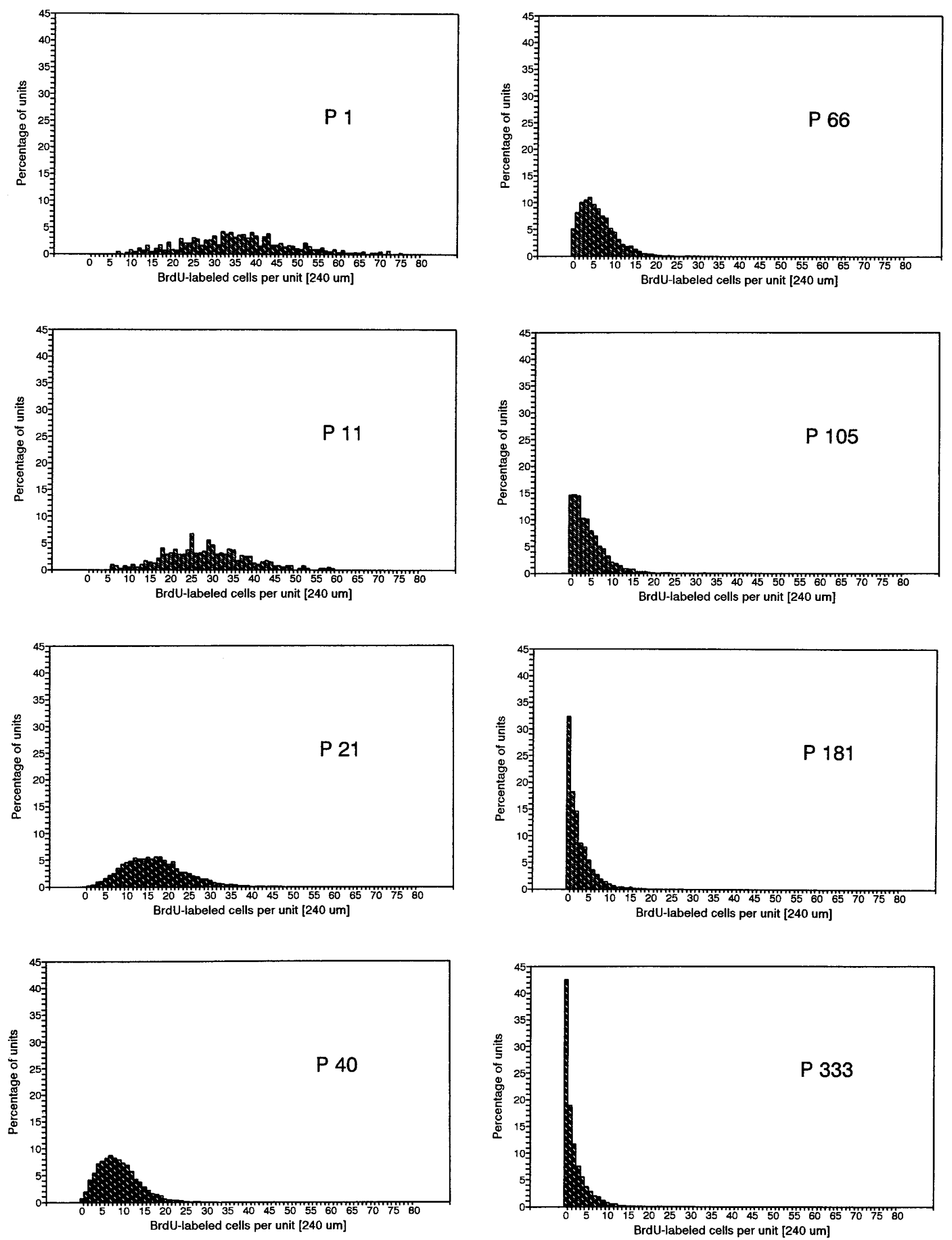

Figure 4. Distribution pattern of the proliferation density. In young animals, more units $(240 \mu \mathrm{m})$ have a high number of labeled cells, whereas in older animals most units have only a few or no labeled cells. 


\begin{tabular}{|c|c|c|c|c|c|c|}
\hline Age & Region 1 & Region 2 & Region 3 & Region 4 & Region 5 & Region 6 \\
\hline P1-3 & $152.74 \pm 17.96$ & $157.63 \pm 18.19$ & $156.49 \pm 7.67$ & $121.02 \pm 19.35$ & $153.40 \pm 9.51$ & $151.63 \pm 2.88$ \\
\hline $\mathrm{P} 11$ & 114.25 & 118.99 & 120.83 & 115.00 & 122.36 & 116.07 \\
\hline $\mathrm{P} 21$ & $73.77 \pm 7.97$ & $71.19 \pm 6.05$ & $69.32 \pm 2.35$ & $68.71 \pm 3.76$ & $69.86 \pm 2.13$ & $70.55 \pm 2.65$ \\
\hline $\mathrm{P} 40$ & $41.21 \pm 8.41$ & $37.28 \pm 3.19$ & $36.35 \pm 3.87$ & $36.44 \pm 3.44$ & $36.02 \pm 3.17$ & $37.52 \pm 3.66$ \\
\hline P66 & $31.79 \pm 7.69$ & $24.10 \pm 2.07$ & $23.21 \pm 2.32$ & $24.39 \pm 1.57$ & $24.31 \pm 2.59$ & $24.75 \pm 2.32$ \\
\hline P105 & $20.00 \pm 5.42$ & $16.95 \pm 2.34$ & $15.91 \pm 0.81$ & $17.03 \pm 1.46$ & $16.81 \pm 1.35$ & $17.70 \pm 2.61$ \\
\hline P181 & $15.82 \pm 2.60$ & $11.66 \pm 1.37$ & $9.64 \pm 0.15$ & $9.07 \pm 1.42$ & $10.10 \pm 1.21$ & $10.58 \pm 1.89$ \\
\hline P333 & $14.71 \pm 2.19$ & $9.26 \pm 0.45$ & $8.35 \pm 0.28$ & $7.07 \pm 0.43$ & $7.10 \pm 0.28$ & $7.05 \pm 0.64$ \\
\hline
\end{tabular}

Mean values and SE for each age group.

tion in the relative number of labeled basal cells counted in each unit. In sections from neonates, we observed a high frequency of units containing $>30$ labeled cells; in contrast, such high values were never seen in old animals. On the other hand, newborn animals showed no units with zero labeled cells, whereas in animals older than $\mathrm{P} 180,>30 \%$ of all units did not contain a single labeled cell. The shape of the distribution pattern changed in an age-dependent manner and the patterns were highly significantly different from one another (Kolmogoroff-Smirnoff test, $p<0.001)$.

One of the characteristics of the distribution of proliferating cells at P40 and later was their distribution in clusters or patches (cf. Moulton et al., 1970; Monti Graziadei and Graziadei, 1979). In newborns (Fig. 5A,D), the labeled cells were so densely packed that they sometimes spanned nearly two rows, and there was hardly any space between them. With increasing age, the labeled cells lined up in a nearly continuous band (Fig. $5 B$ ) and later appeared in clusters (Fig. 5C,E,F), first observable at P40. The clustering of labeled cells became progressively easier to observe at P66 and older. However, in the oldest animals (P333), the number of cells within a cluster became smaller and sometimes extents of epithelium several millimeters long were found without a single labeled cell (Fig. 5C). This is reflected in Figure 4 by the high frequency of units $(>40 \%)$ with zero labeled cells and the high frequency of units $(>40 \%)$ with few (1-5) labeled cells.

\section{Regional and area differences}

We have noted that the proliferating cells appeared in patches and, further, the number of labeled cells per unit from one 240 $\mu \mathrm{m}$ unit to another varied widely in the same animal and in the same section. Moreover, among the six anteroposterior regions taken from an individual animal, the local differences in the proliferation density varied by as much as $30 \%$. Nevertheless, the average values among five of the six regions ranging from anterior to posterior showed no differences in proliferation density in all age groups (Fig. 6, Table 2). The only exception was the most anterior region; beginning at P21 and in all older age groups, the count in the anterior region was slightly higher. In the age groups P181 and P333, the proliferation densities in the most anterior region were significantly higher than those in the other five regions $(p<0.005)$. Moreover, region 1 in each age group showed the most variability. This is consistent with the fact that this region is most vulnerable to damage, i.e., most exposed to drying out and to the effect of airborne pollutants or potential cytotoxic agents and infectious organisms from the environment. If more cells in this region die, there would be a greater demand for replacement cells. Moreover, much of the incremental growth in area would also occur in that region. That growth occurs anteriorly is reflected in the area profiles (Fig. 8); the anterior part of the profile becomes longer in older rats, and the major region of olfactory epithelium shifts posteriorly.

We analyzed the proliferation density in the different areas within a region, e.g., the septum versus the different turbinates. The number of BrdU-labeled basal cells in the septum generally was lower than the average of the entire section in a given region. Lower values were also seen in the second and third endoturbinates, compared with the ectoturbinates. This occurred more frequently in younger age groups than in older ones. These differences, however, were not statistically significant.

\section{Sex differences}

Despite the fact that the males and females showed a different rate of growth from P25 onward, and even though the differences in their body weights after that age were statistically significant (Fig. 2), no differences in the proliferation density (Fig. 3) or distribution pattern at any investigated age were detected.

\section{Differences between right and left sides}

Right-left side differences in the density of BrdU-labeled basal cells for individual animals ranged from $-16 \%$ to $+14 \%$ (Fig. 7 ), if the value for the right side is arbitrarily set at $100 \%$. The variations in values between right and left sides of regions or even single sections were sometimes even greater; however, there was no pattern suggesting that one side was consistently higher than the other in any age group. The percent differences were larger in older animals, probably because the values were lower and a small absolute difference made a high relative difference. These variations might be related to the nasal cycle, i.e., the cyclic $(\sim 2-3 \mathrm{hr})$, autonomically controlled partial closure of one naris. Although the differences between right and left seemed high in individual animals, the differences in the proliferation density within any age group were not statistically significant.

\section{Proliferation density of other structures}

Although we made no counts of BrdU-labeled cells in other regions of the nasal cavity, we did note an obvious decrease in proliferation density with age in the organ of Masera (septal organ), a patch of olfactory epithelium located on the anterior ventral part of the septum. Similarly, in the vomeronasal organ, there was a clear decrease of proliferation density with age. In addition, the number of BrdU-labeled supporting cells in all olfactory epithelia declined with age.

Respiratory epithelium covers most of the nasal cavity and parts of the turbinates. Like the olfactory epithelium, it is repaired by 


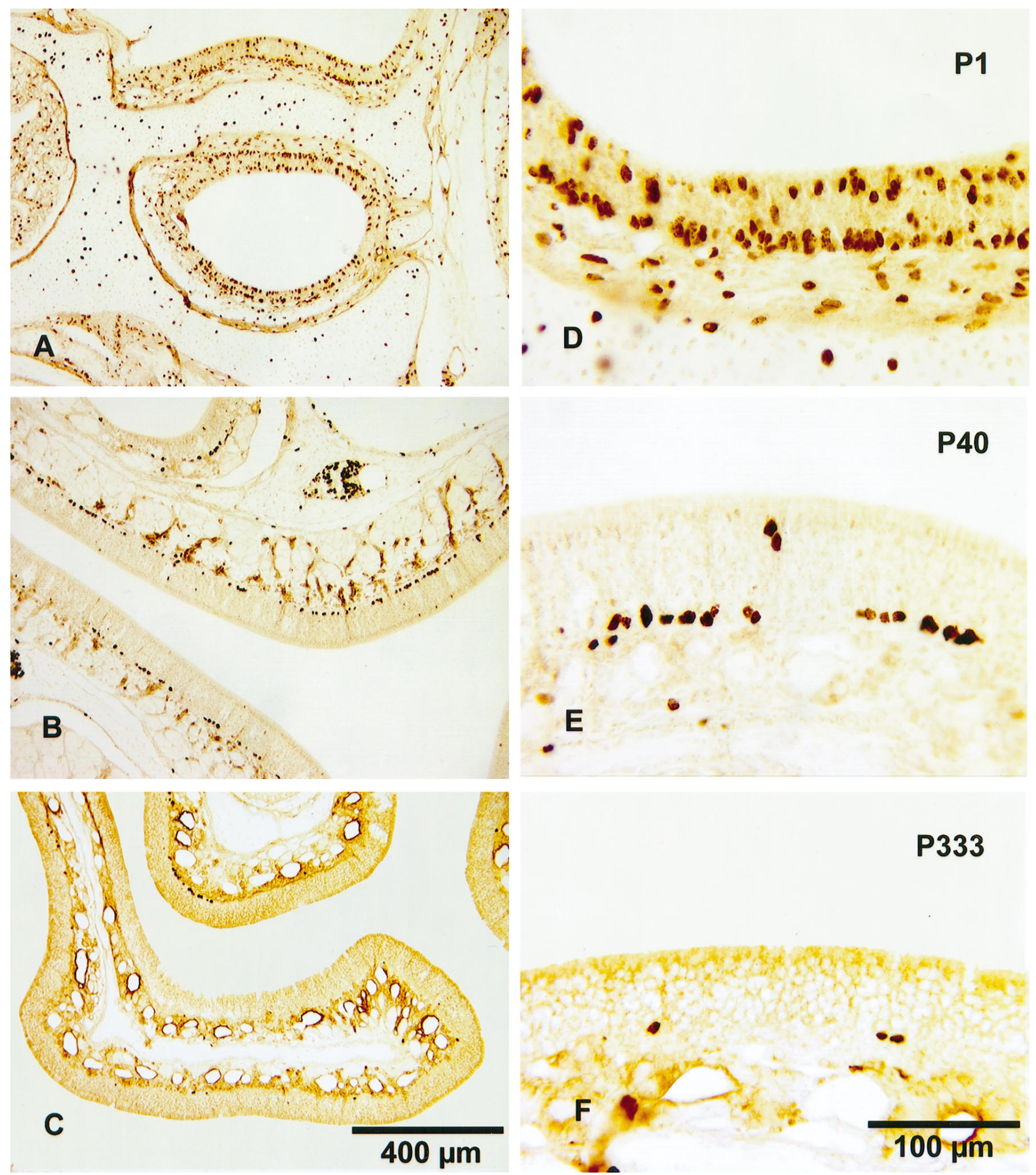

Figure 5. BrdU-labeled cells in the olfactory epithelium of animals at $\mathrm{P} 1(A, D), \mathrm{P} 40(B, E)$, and $\mathrm{P} 333(C, F)$. The frequency of the labeled cells decreases dramatically with age. Whereas in newborns, the basal cells are so close together that they span nearly two rows $(D)$, in P40 animals they form one line and/or are arranged in clusters $(E)$. In P333 animals the clusters contain fewer cells and there are long spaces between clusters $(F)$. The $400 \mu \mathrm{m}$ marker in $C$ also applies to $A$ and $B$, and the $100 \mu \mathrm{m}$ marker in $F$ also applies to $D$ and $E$.

replacement of the cells differentiating from daughter cells of mitotic basal cells. Here, too, it was readily apparent that the density of proliferating basal cells decreases with age, although again we did not make any counts.

\section{Area of the olfactory epithelium}

The area of the olfactory epithelium increases continuously with age in the range of ages we studied (Figs. 8, 15). This result confirms the data of others who measured area in postnatal rats 


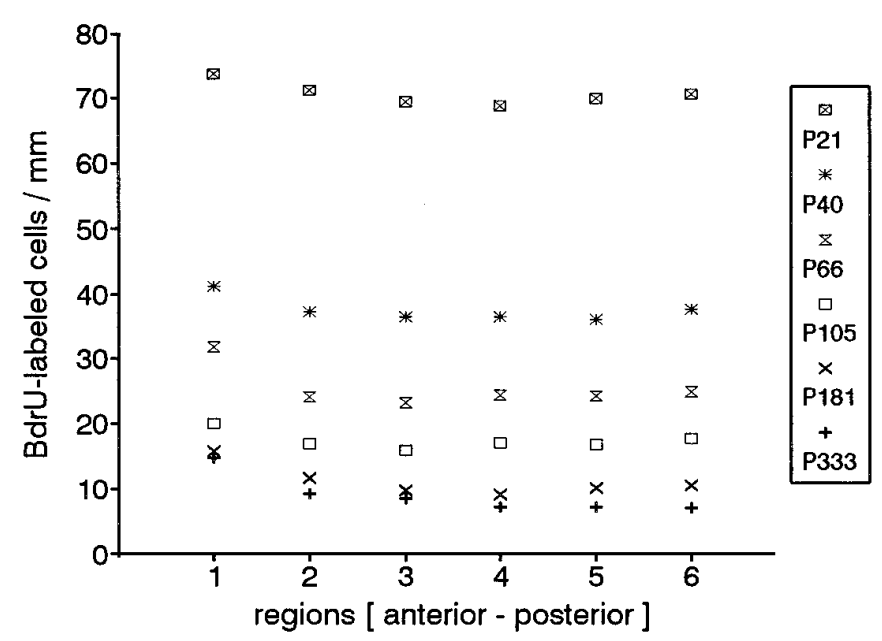

Figure 6. Proliferation density in the different regions ranging from anterior to posterior. There are no differences in the mean values among the regions (except region 1, see text). This is true for all age groups. Animals younger than P21 are not shown, because at those ages the regions are not exactly the same as in the other groups owing to the allometric growth of the turbinates. The SE values are omitted for clarity, but are included in Table 2 .

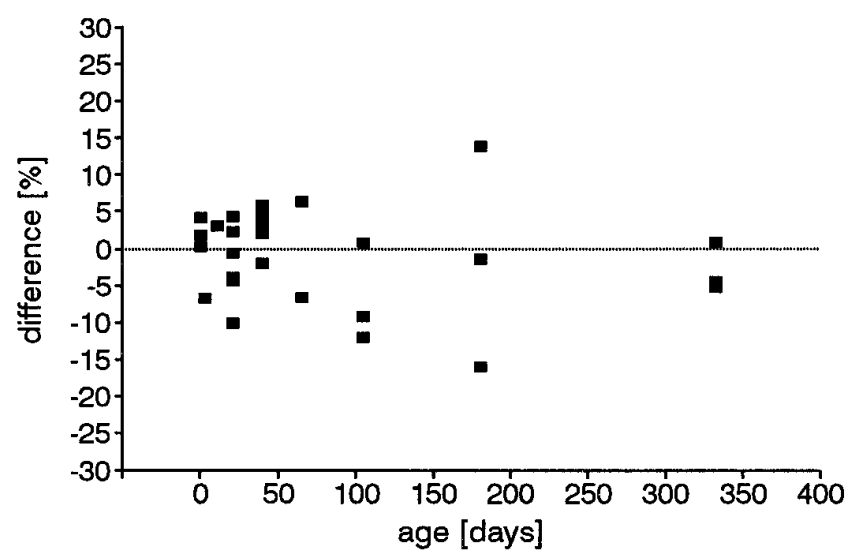

Figure 7. Proliferation density differences between the right and left sides of the olfactory epithelium in individual animals with the right side set at $100 \%$. There is no trend or significant difference within any of the age groups.

from P1 to P90 (Meisami, 1989; Paternostro and Meisami, 1993) or used a different method and concentrated their measurements to the epithelium lining the septum (Hinds and McNelly, 1981; Apfelbach et al., 1991).

The profile of the area has a typical shape from anterior to posterior in the postweanling animals (Fig. 8; cf. Paternostro and Meisami, 1993). Moreover, the size of the anterior flat region of the curve increases with age so that the major part of the olfactory epithelium shifts posteriorly. This is consistent with the observation that the anterior region has the highest proliferative density. The length of epithelium begins to increase dramatically when the first ectoturbinate emerges and the second ectoturbinate acquires olfactory (rather than respiratory) epithelium. The shoulder of the curve preceding the apex is the region where the fourth endoturbinate appears, but is not yet covered with olfactory epithelium. More posteriorly, when olfactory epithelium covers this endoturbinate, the curve becomes steep again. The maximal length of olfactory epithelium is reached when all the turbinates are seen in

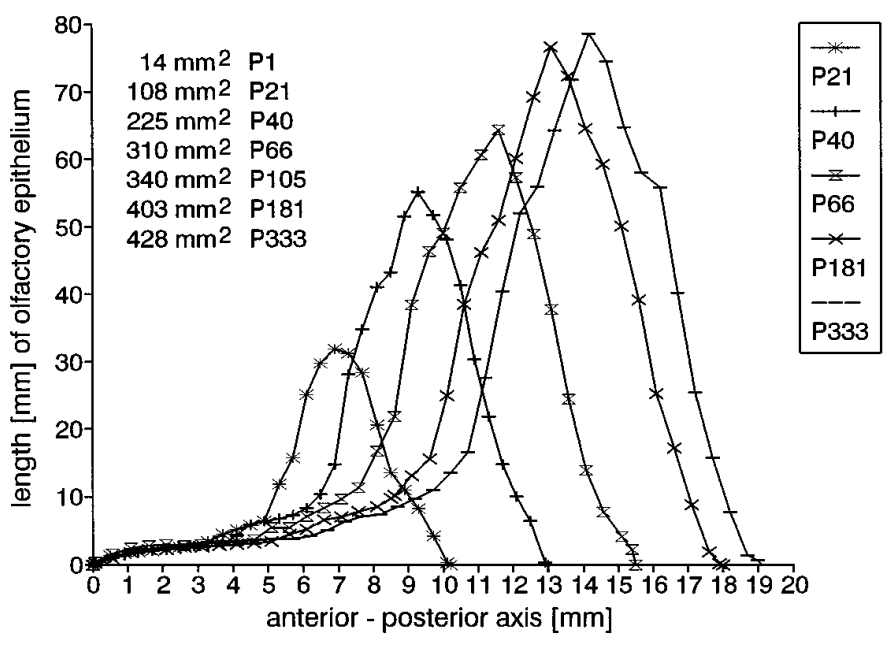

Figure 8. Typical distribution profiles of the extent of olfactory epithelium from anterior to posterior at different ages. Each point represents the length of olfactory epithelium on the right side measured in a frontal section at the respective level of the anterior-posterior axis. Zero represents the most rostral beginning of the olfactory epithelium. The area under each of these curves represents the area of the right olfactory sensory sheet in the respective animal. The area increases continuously during postnatal development. For clarity, the P1 and P105 curves are not shown, but the area values are given.

a single frontal section (region 3) before fusion of any turbinates. When the second endoturbinate begins to fuse (region 4), the length of olfactory epithelium in a section declines.

\section{Olfactory epithelium thickness}

Proliferation in the rat olfactory epithelium is required to provide new cells both for the age-related increase in the total olfactory surface area (Figs. 8, 15) and for the replacement of dying cells. Given that the total epithelial thickness is related to the number of neuronal cells (Mackay-Sim et al., 1988) and that both thickness and number are variable, it was deemed necessary to relate the proliferation density data to possible age-related changes in epithelial thickness and to the total number of various cell types within the epithelium.

The average thickness of the olfactory epithelium, measured from the basal lamina to the apical surface, showed agedependent changes (Fig. 5). There was an increase in average thickness of $40 \%$ from birth to P40, whereas afterwards the average thickness decreased. The decrease continued in adults (Fig. 9). The probability is very high that the increase and decrease are real (Mann-Whitney $U$ test, $p<0.001)$. No differences between males and females could be detected. The changes in thickness are not related to the decrease in number of proliferating cells with age.

It should be noted that although there was wide variability in the olfactory epithelium thickness, ranging in our study from 24 to $133 \mu \mathrm{m}$, one generalization can be made. Epithelium lining a convex structure was usually thicker than that lining a concave structure. The thickness of the epithelium lining the septum and turbinate edges (convex) was higher than the thickness in the vicinity where the turbinates were connected to the lateral wall (concave) or to other concave parts of the turbinates. It was clear from our observations that the decrease in epithelial thickness in the adult animals was real and not a result of any large increase in length of the concave or connecting parts with age, nor was it an artifact of oblique sectioning. 


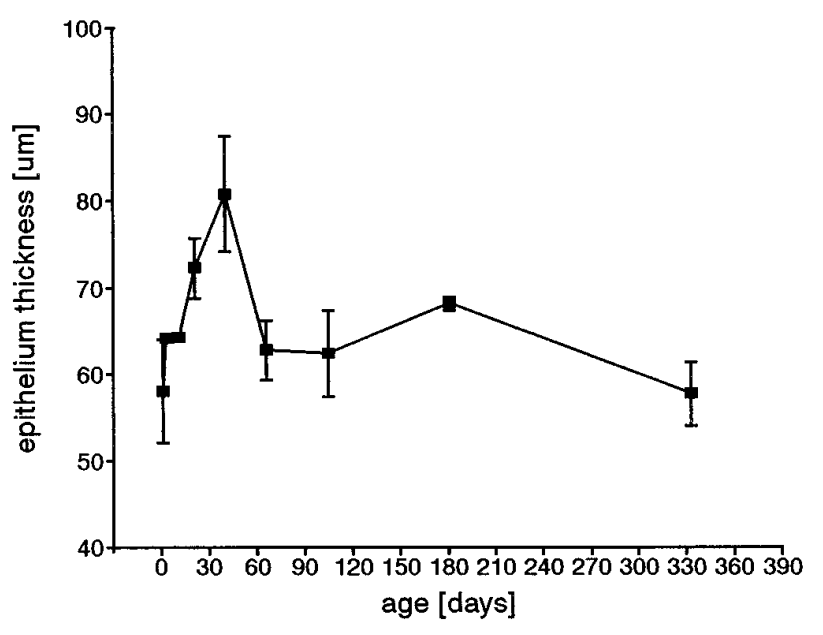

Figure 9. The epithelial thickness changes postnatally. There is an increase in thickness until P40, followed by a continuous decrease. Mean values and SD values are given for the different age groups.

\section{Cell density}

Because it is possible that the number of cells within a given length or volume of epithelium might not be constant, even if the epithelial thickness is constant, we estimated the number of nuclei of the three major epithelial cell types over a length of epithelium at different ages and different epithelium thicknesses. The data showed that in each age group there was a direct correlation between epithelial thickness and the number of neurons per unit length, thus confirming the data of others (cf. Mackay-Sim et al., 1988). Representative data are shown in Figure 10 for P21, and although the other data are not shown, this was true in all age groups. However, the neuronal density (number of neurons per unit length) in the different age groups was not always the same, even when the epithelial thickness was the same. We arbitrarily selected a thickness of $60 \mu \mathrm{m}$ to evaluate neuronal density and by a linear regression calculation determined that in newborn animals (P1), there were 190 neurons in a $200 \mu \mathrm{m}$ length of epithe-

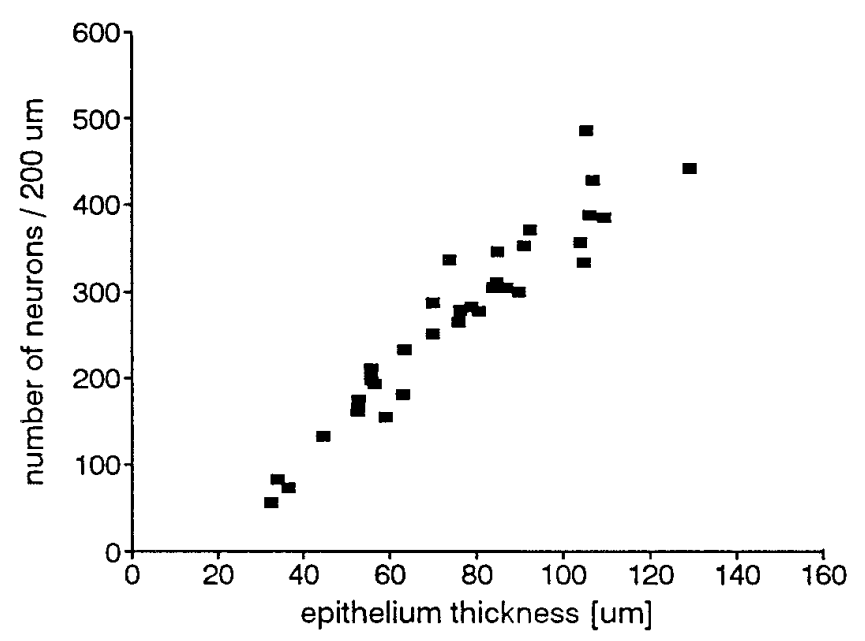

Figure 10. Number of nuclear profiles of neurons in a length of $200 \mu \mathrm{m}$ olfactory epithelium at different thicknesses of the epithelium in P21 animals. There is a strong linear correlation between the number of neurons and the thickness of the epithelium. The number of cell nuclei increases with epithelial thickness. Each point represents the number of nuclei, the profiles for which lie within the $10 \mu \mathrm{m}$ section, between the supporting cells and the basal cells.

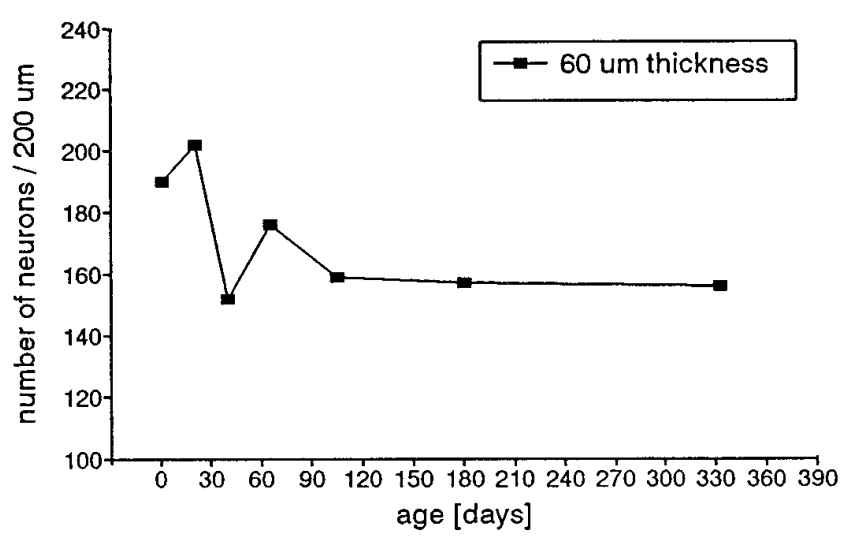

Figure 11. Number of nuclear profiles of neurons at different ages in a $200 \mu \mathrm{m}$ length of olfactory epithelium and with a given thickness of $60 \mu \mathrm{m}$. The numbers were calculated for this thickness from the linear regression curves from the values in each age group. There is an increase in cell density from birth to P 21 and then a decrease. The density stays nearly constant from P105.

lium. This density increased to a peak of 202 at P21. In older age groups the density decreased and reached a plateau value of 160 from P105 on (Fig. 11). Thus, the change in density of neurons, even within a constant epithelial thickness, implies either a modification in their individual volumes, or perhaps a modification in the total volume occupied by the other cell types in the epithelium. However, the change in neuron density does not account for the dramatic decrease in proliferation density.

\section{Age-related change in ratio between number of proliferating cells and total number of neurons}

It was of interest to determine whether the ratio between the number of basal cells incorporating BrdU and the total number of neurons per unit length changes with age, because this could have profound effects on the population dynamics. In other words, if this ratio remained the same at all ages, it would mean that there were no age-related changes in the growth rate of the total surface area and/or no difference in the rate at which cells are replaced. However, a decrease in this ratio between proliferating cell number and total neuron number might suggest, for example, that mature cells are living longer or that the rate of growth slows down, or the length of the cell cycle is increased.

In the assessment of this ratio, we did not limit our observations to a calculated value for a single thickness, as in Figure 11, but included all values at all thicknesses. We observed that the total number of neurons declined with age from an average high of $\sim 1300 / \mathrm{mm}$ length at P21 to a low of $<800 / \mathrm{mm}$ at P333 (Fig. 12). Accompanying the steep decline in total neuron number per unit length was an even greater reduction in the proportion of basal cells incorporating BrdU, from $\sim 30 \%$ of the basal cells at P1, the percentage fell to $<5 \%$ at P333 (Fig. 13). This is consistent with the possibility that the cell cycle becomes longer or that there are fewer basal cells in the cell cycle at any given time (i.e., more cells in $\mathrm{G}_{0}$ ). Although the number of neurons/unit length decreased, the number of proliferating cells/unit length decreased even more; this was reflected in a decrease in the percentage of BrdUlabeled basal cells within the combined basal cell plus neuron population (Fig. 13). Thus, with age, the number of proliferating cells per unit length declined at a greater rate than the total number of neurons. This is consistent with the possibility that the neurons live longer. 


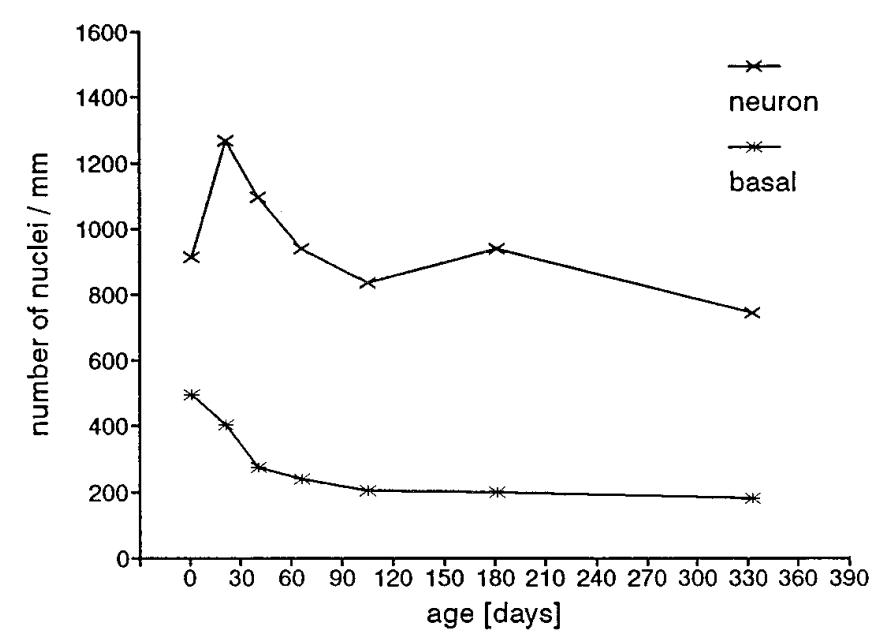

Figure 12. Number of neuronal profiles per millimeter length for the average thickness for each age group. The values in this graph were calculated from the linear regression curves for each age group. The number of neurons per millimeter length of the olfactory epithelium increases at P21 and then decreases almost continuously. This means that the total number of neurons in a given area would decline. The number of basal cells declines continuously from P1.

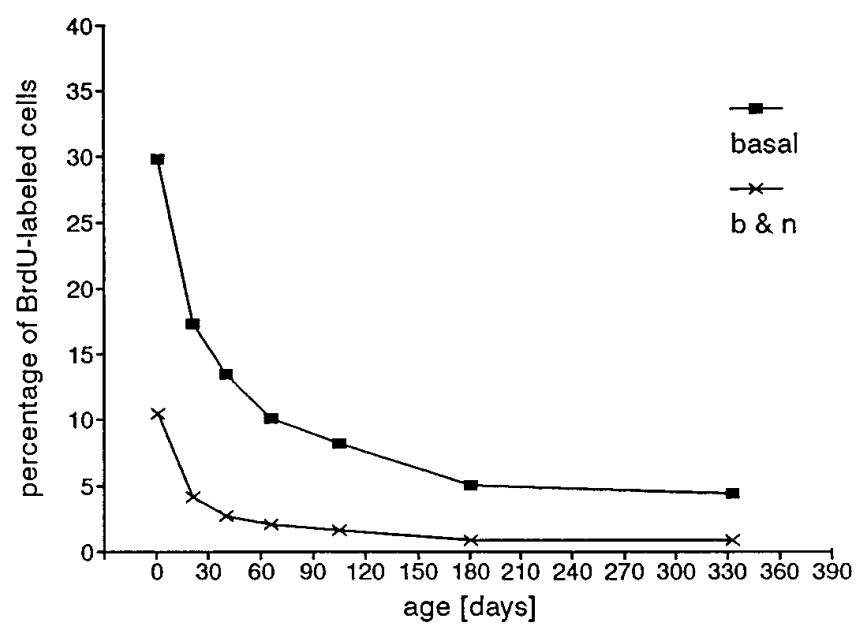

Figure 13. Percentage of BrdU-labeled cells in the basal cell compartment [number of BrdU-labeled cells divided by total number of basal cells $(\square)$ ]. The lower curve $(\times)$ represents the calculated percentages of BrdUlabeled cells of the total number of neurons plus basal cells.

The ratio between the number of neurons and number of proliferating basal cells changed dramatically from 6:1 at P1 to 93:1 from P181 on (Fig. 14). In the rapidly growing olfactory epithelium of the P1 rat, the primary function of proliferating basal cells is very likely directed to increasing the total neuron population and surface area, whereas at P333, when surface area is growing much more slowly (Figs. 8, 15; Hinds and McNelly 1981), the major function of proliferation is replacement. Our results suggest that at P181, only a small population of proliferating basal cells, probably $<5 \%$, is directed to growth in area, whereas most of proliferation provides a pool for replacement.

\section{DISCUSSION}

Our results clearly show that age has an important influence on the number of BrdU-labeled basal cells $/ \mathrm{mm}$ epithelial length in the rat olfactory epithelium. We observed a dramatic asymptotic

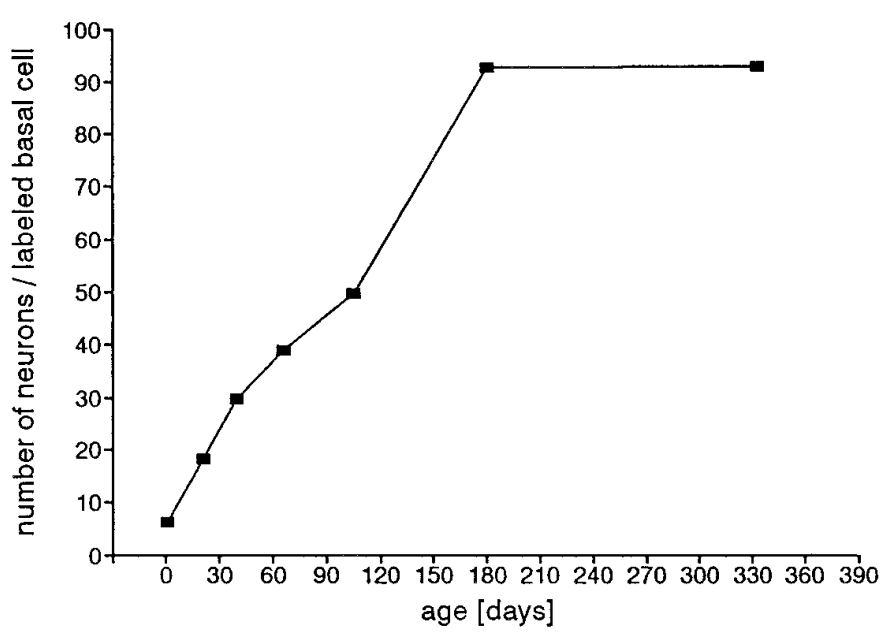

Figure 14. The ratio of the number of neurons to the number of BrdU-labeled basal cells changes significantly with age, from $6: 1$ in the neonate to 93:1 at P181 and P333.

decrease in proliferation density; the density in the 11-month-old rat was only $5 \%$ of that in the newborn.

Although there is a substantial difference in body size between adult male and female rats of the same age (Fig. 2) there was no sex-linked difference in proliferation density within any age group. This is consistent with the observations of others who showed that change in growth of the animal body size induced by thyroxin deficiency (Mackay-Sim and Beard, 1987; Paternostro and Meisami, 1993) or excess of growth hormones (Meisami et al., 1994) did not change the proliferation density in the olfactory epithelium. The importance of this observation lies in the possibility that a 200 gm male laboratory rat with no dietary restrictions can be as young as $36 \mathrm{~d}$ or as old as $56 \mathrm{~d}$. Our data show that there would be a nearly twofold difference in proliferation density in rats at these two ages, although they might have the same body weight. Therefore, our data stress the importance of using age-matched controls in studies on proliferation density, rather than body weight-matched rats.

\section{Patchy distribution of proliferating cells}

We confirmed the data of others that proliferating basal cells appear in patches or clusters (Moulton et al., 1970; Graziadei and Monti Graziadei, 1979; Monti Graziadei and Graziadei, 1979; Suzuki and Takeda, 1993; Huard and Schwob, 1995). The number of clusters and labeled cells within a cluster was reduced with age. The patchy distribution of mitotic cells is consistent with the notion that the microenvironment is conducive for cell division, possibly because of the existence of a local stimulus that activates the cell cycle in several neighboring progenitor cells.

Another possible interpretation of why proliferative cells occur in clusters can be extrapolated from the data of Mackay-Sim and Kittel (1991b). They showed that the progenitor cell population of olfactory epithelium, the globose basal cells, can undergo two or more symmetric cell divisions before they leave the cell cycle and begin differentiation. In other words, a single globose basal cell divides symmetrically to give rise to two daughter cells, and each of these in turn could divide symmetrically to give rise to a total of four, etc. The clustering of BrdU-positive cells might then be explained by the existence of several neighboring progenitor cells with synchronized cell cycles. This would also be consistent with 


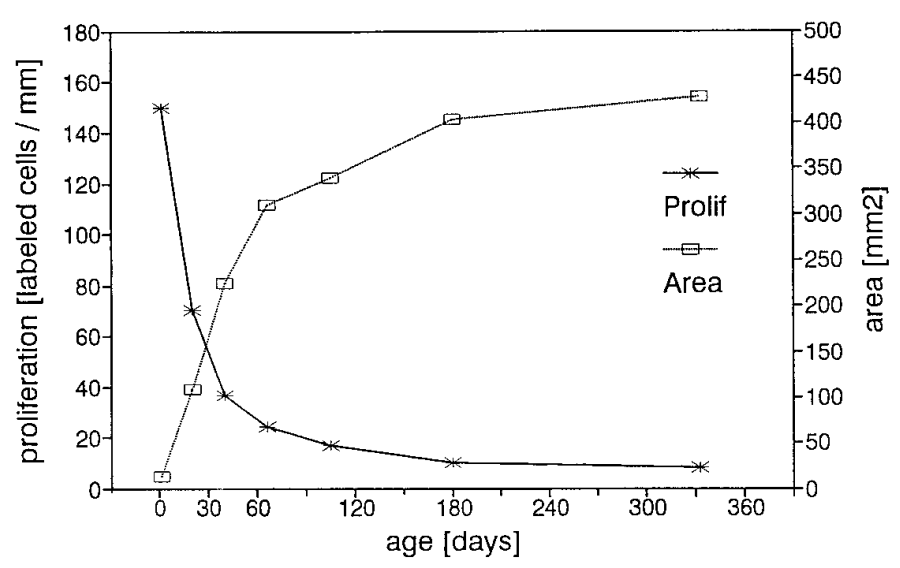

Figure 15. This graph shows the increase of the area of the olfactory sheet in postnatal development superimposed on the proliferation density (see Fig. 3). Area and proliferation density change reciprocally.

the notion stated above, namely, that a local stimulus could be responsible for initiating cell division in an individual patch.

\section{Is the number of proliferating olfactory cells constant throughout life in the rat?}

Our data and other studies on rat olfactory epithelium have shown that to the age of 18 months, there is an increase in the total area of the olfactory sheet associated with an increase in the total number of olfactory neurons (Hinds and McNelly, 1981; Meisami, 1989; Apfelbach et al., 1991; Paternostro and Meisami, 1993). The age-dependent decrease in proliferation density in the rat is reciprocally related to the continuous increase in the area covered by olfactory epithelium. We have used our area data to construct a curve (Fig. 15) depicting olfactory surface area and have superimposed this curve on a copy of the proliferation density curve from Figure 3. The total pool of BrdU-positive basal cells is distributed over a 25- to 30-fold larger epithelial surface area from the neonate to 11 months, resulting in a reduction of proliferation density. Although the density of labeled cells changes with age, the total number actually does not change a great deal, certainly by less than a factor of two in this study. In the very young rat, many or most of these proliferating cells probably contribute to the rapidly growing surface area of the olfactory epithelium as well as to the replacement of dying cells, whereas in later life when the rate of growth is considerably slower, their role may be more directed to cell replacement.

If the total number of proliferating cells remains nearly constant over the life of the animal, we must consider the possibility that some regulatory mechanism is acting to maintain this number. The number can be upregulated after bulbectomy (Costanzo, 1984; Schwartz Levey et al., 1991; Carr and Farbman, 1992), axotomy (cf. Nagahara, 1940; Costanzo and Graziadei, 1983; Nakamura, 1991; Suzuki and Takeda, 1991), direct destruction of the epithelium (Rehn et al., 1981; Cancalon, 1982; Schwob et al., 1995), or even by reducing the number of mitral cells in the bulb (Weiler and Farbman, 1996). The number can be downregulated after naris occlusion (Farbman et al., 1988; Cummings and Brunjes, 1994). We suggest that dying cells may be the source of a local trigger that directly or indirectly promotes upregulation of mitotic rate, and that a downregulating signal might be derived from mature sensory neurons. In older animals or in animals with unilateral naris closure, where the relative proportion of mature cells to total neurons is higher than in young adults, the balance would shift to a lower proliferation density.

The bulb contributes to mitotic regulation in the epithelium by maintaining the survival of neurons, presumably by delivering to them a trophic factor (Schwob et al., 1992). If this were true, there would have to be an increased supply of trophic substance to support survival of an increased number of neurons projecting to a constant number of mitral cells (Hinds and McNelly, 1981; Meisami, 1989). The convergence ratio of olfactory to mitral cells increases strikingly from 25:1 in the newborn rat to 250:1 at P25 (Meisami, 1989). In adult rabbits, the convergence may be as much as 6500:1 (Allison and Warwick, 1949). Morphometric measurements show that with age, mitral cells increase in size (Hinds and McNelly, 1981) and continue to produce GAP43, a protein known to be associated with neuron growth (Zhang et al., 1995). In addition, with increase in age, there is an increase in the number of periglomerular cells in the target region (Altman, 1969; Bayer, 1983; Alvarez-Buylla and Lois, 1995). The growth of mitral cells and/or the increased numbers of periglomerular cells in the target region provide more space for synapses, and the increased amount of target could be related to an increased production of trophic factor.

\section{Do olfactory neurons in older animals live longer?}

In mice raised in a filtered air environment, individual olfactory cells can live as long as 12 months (Hinds et al., 1984). Moreover, there is evidence for a greater density of mature neurons with advancing age in rats, if one uses as a sign of maturity the presence of a dendritic knob (Hinds and McNelly, 1981) or the relative proportion of mature neurons (OMP-positive cells) versus immature (B50/GAP43-positive) cells (Verhaagen et al., 1989). In some studies on cell dynamics during postnatal development, it was shown that the ratio between the number of dendritic knobs and the total number of neuronal cell bodies in a given volume of olfactory epithelium increases with age in ferrets, rats, and mice (Schmidt, 1989; Russ, 1989; Walker et al., 1990). These data are consistent with the notion that at least some olfactory neurons live longer in older animals. Other possible explanations for the higher proportion of mature cells and relatively fewer "almost mature" cells include the possibility that (1) some postmitotic cells die precociously, either for lack of trophic support from the bulb or for other reasons, and (2) an increase in the length of the cell cycle, i.e., fewer cells would likely be in the S-phase at the time of injection.

Our data do not permit one to make conclusions about the average life span of olfactory neurons or about the life span of individual cells. In fact, it may not even be useful to consider the average life span of the population of neurons, because its composition can change with age or unilateral naris occlusion. In both cases, the balance shifts in favor of mature neurons. It may be that life spans of olfactory neurons do not fit a Gaussian distribution but a distribution in which a high proportion of cells dies young, a high proportion lives for relatively long periods, and few cells live for intermediate periods. In contrast, younger animals have a significant population of "almost mature" (GAP43-positive) cells. Our data are consistent with the possibility that at least in older animals, when the growth rate has slowed, those olfactory neurons that reach maturity do live longer. More information is needed, however, to make intelligent estimates of life spans. For example, one must know how likely it is that a BrdU-labeled cell at any age will survive to maturity. 


\section{Conclusion}

In summary, the significance of the age-related changes in the distribution of labeled olfactory progenitor cells may be attributable to any one or more of the following reasons: (1) there is less "demand" for replacement neurons in unperturbed older animals, because existing neurons live longer; (2) fewer new neurons are needed for an expanding olfactory area, because the rate of growth in older animals is much smaller; (3) in older rats there is a reduced number of symmetric divisions of progenitor cells (resulting in fewer cells per cluster); or (4) fewer cells are labeled because the cell cycle time is longer. At any age, however, when the demand for replacement is induced experimentally by massive cell death after olfactory bulbectomy or axotomy, the system is presumably able to respond by increasing the number of divisions in the progenitor cell population (Schwartz Levey et al., 1991; Suzuki and Takeda, 1991).

\section{REFERENCES}

Abercrombie M (1946) Estimation of nuclear population from microtome sections. Anat Rec 94:239-247.

Allison AC, Warwick RTT (1949) Quantitative observation on the olfactory system of the rabbit. Brain 72:186-197.

Altman J (1969) Autoradiographic and histological studies of postnatal neurogenesis. IV. Cell proliferation and migration in the anterior forebrain, with special reference to persisting, neurogenesis in the olfactory bulb. J Comp Neurol 137:433-458.

Alvarez-Buylla A, Lois C (1995) Neuronal stem cells in the brain of adult vertebrates. Stem Cells 13:263-272.

Apfelbach R, Russ D, Slotnick BM (1991) Ontogenetic changes in odor sensitivity, olfactory receptor area and olfactory receptor density in the rat. Chem Senses 16:209-218.

Bayer SA (1983) 3H-thymidine-radiographic studies of neurogenesis in the rat olfactory bulb. Exp Brain Res 50:329-340.

Cancalon P (1982) Degeneration and regeneration of olfactory cells induced by $\mathrm{ZnSO}_{4}$ and other chemicals. Tissue Cell 14:717-733.

Carr VM, Farbman AI (1992) Ablation of the olfactory bulb upregulates the rate of neurogenesis and induces precocious cell death in olfactory epithelium. Exp Neurol 115:55-59.

Coggeshall RE, Lekan HA (1996) Methods for determining numbers of cells and synapses: a case for more uniform standards of review. J Comp Neurol 364:6-15.

Costanzo RM (1984) Comparison of neurogenesis and cell replacement in the hamster olfactory system with and without a target (olfactory bulb). Brain Res 307:295-301.

Costanzo RM, Graziadei PPC (1983) A quantitative analysis of changes in the olfactory epithelium following bulbectomy in hamster. J Comp Neurol 215:370-381.

Cummings DM, Brunjes PC (1994) Changes in cell proliferation in the developing olfactory epithelium following neonatal unilateral naris occlusion. Exp Neurol 128:124-128.

Dodson HC, Bannister LH (1980) Structural aspects of ageing in the olfactory and vomeronasal epithelia in mice. In: Olfaction and taste VII (Van der Starre H, ed), pp. 151-154. Oxford: IRL.

Farbman AI (1992) Cell biology of olfaction. New York: Cambridge UP.

Farbman AI, Brunjes PC, Rentfro L, Michas J, Ritz S (1988) The effect of unilateral naris occlusion on cell dynamics in the developing rat olfactory epithelium. J Neurosci 8:3290-3295.

Graziadei PPC, Metcalf J (1971) Autoradiographic and ultrastructural observations on the frog's olfactory mucosa. Z Zellforsch 116:305-318.

Graziadei PPC, Monti Graziadei AG (1979) Neurogenesis and neuron regeneration in the olfactory system of mammals. I. Morphological aspects of differentiation and structural organization of the olfactory sensory neurons. J Neurocytol 8:1-18.

Hayashi Y, Koike M, Matsutani M, Hoshino T (1988) Effects of fixation time and enzymatic digestion on immunohistochemical demonstration of bromodeoxyuridine in formalin-fixed, paraffin-embedded tissue. J Histochem Cytochem 36:511-514.

Hinds JW, McNelly NA (1981) Aging in the rat olfactory system: correlation of changes in the olfactory epithelium and olfactory bulb. J Comp Neurol 203:441-453.

Hinds JW, Hinds PL, McNelly NA (1984) An autoradiographic study of the mouse olfactory epithelium: evidence for long-lived receptors. Anat Rec 210:375-383.

Holtmaat AJGD, Dijkhuizen PA, Oestreicher AB, Romijn HJ, Van der Lugt NMT, Berns A, Margolis FL, Gispen WH, Verhaagen J (1995) Direct expression of the growth-associated protein B-50/GAP-43 to olfactory neurons in transgenic mice results in changes in axon morphology and extraglomerular fiber growth. J Neurosci 15:7953-7965.

Huard JMT, Schwob JE (1995) Cell cycle of globose basal cells in rat olfactory epithelium. Dev Dyn 203:17-26.

Lienert GA (1973) Verteilungsfreie Methoden in der Biostatistik. Verlag Anton Hain, Meisenheim am Glan, Bd I.

Mackay-Sim A, Beard MD (1987) Hypothyroidism disrupts neural development in the olfactory epithelium of adult mice. Dev Brain Res 36:190-198.

Mackay-Sim A, Breipohl W, Kremer M (1988) Cell dynamics in the olfactory epithelium of the tiger salamander: a morphometric analysis. Exp Brain Res 71:189-198.

Mackay-Sim A, Kittel PW (1991a) On the life span of olfactory receptor neurons. Eur J Neurosci 3:209-215.

Mackay-Sim A, Kittel PW (1991b) Cell dynamics in the adult mouse olfactory epithelium: a quantitative autoradiographic study. J Neurosci 11:979-984.

Meisami E (1989) A proposed relationship between increases in the number of olfactory receptor neurons, convergence ratio and sensitivity in the developing rat. Dev Brain Res 46:9-19.

Meisami E, Paternostro MA, Dehsi SS (1994) Role of excess thyroxin and growth hormone in postnatal increase of surface area and receptor neuron number in the olfactory epithelium of growing rats. In: Advances in the Biosciences, Vol. 93, (Apfelbach R, Müller-Schwarze D, Reutter K, Weiler E, eds), pp 605-610. New York: Elsevier Science, Pergamon.

Monti Graziadei GA, Graziadei PPC (1979) Neurogenesis and neuron regeneration in the olfactory system of mammals. II. Degeneration and reconstitution of the olfactory sensory neurons after axotomy. J Neurocytol 8:197-213.

Moulton DG (1975) Cell renewal in the olfactory epithelium of the mouse. In: Olfaction and taste. V. (Denton DA, Coghlan JP, eds), pp 111-114. New York: Academic.

Moulton DG, Celebi G, Fink RP (1970) Olfaction in mammals-two aspects: proliferation of cells in the olfactory epithelium and sensitivity to odours. In: Ciba foundation symposium on taste and smell in vertebrates. (Wolstenholme GEW, Knight J, eds), pp. 227-250. London: Churchill.

Nagahara Y (1940) Experimentelle Studien über die histologischen Veränderungen des Geruchsorgans nach der Olfactoriusdurchschneidung. Beiträge zur Kenntnis des feineren Baus des Geruchsorgans. Jap J Med Sci V, Pathol 5:165-199.

Nakamura H (1991) Immunohistochemical observations of dividing cells in olfactory epithelium using anti-BrdU antibody. Eur Arch Otorhinolaryngol 248:298-301.

Paternostro MA, Meisami E (1993) Developmental plasticity of the rat olfactory receptor sheet as shown by complete recovery of surface area and cell number from extensive early hypothyroid growth retardation. Dev Brain Res 76:151-161.

Paternostro MA, Meisami E (1994) Quantitative [ $\left.{ }^{3} \mathrm{H}\right]$ thymidine autoradiography of neurogenesis in the olfactory epithelium of developing normal, hypothyroid and hypothyroid-rehabilitated rats. Dev Brain Res 83:151-162.

Rehn B, Breipohl W, Schmidt C, Schmidt U, Effenberger F (1981) Chemical blockade of olfactory perception by $N$-methyl-formiminomethylester in albino mice. II. Light microscopical investigations. Chem Senses 6:317-328.

Russ D (1989) Die postnatale Entwicklung der Regio olfactoria der Laborratte. MA thesis, University of Tübingen, Germany.

Sachs L (1982) Applied statistics. New York: Springer.

Schmidt R (1989) Die postnatale Entwicklung der Regio olfactoria des Frettchens (Mustela putorius $f$. furo L.). MA thesis, University of Tübingen, Germany.

Schwartz Levey M, Chikaraishi DM, Kauer JS (1991) Characterization of potential precursor populations in the mouse olfactory epithelium using immunocytochemistry and autoradiography. J Neurosci 11:3556-3564.

Schwob JE, Szumowski KEM, Stasky AA (1992) Olfactory sensory neurons are trophically dependent on the olfactory bulb for survival. J Neurosci 12:3896-3919. 
Schwob JE, Youngentob SL, Mezza RC (1995) Reconstitution of the rat olfactory epithelium after methyl bromide-induced lesion. J Comp Neurol 359:15-37.

Smart IHM (1971) Location and orientation of mitotic figures in the developing mouse olfactory epithelium. J Anat 109:243-251.

Suzuki Y, Takeda M (1991) Basal cells in the mouse olfactory epithelium after axotomy: immunohistochemical and electron microscopic studies. Cell Tiss Res 266:239-245.

Suzuki Y, Takeda M (1993) Basal cells in the mouse olfactory epithelium during development: immunohistochemical and electron-microscopic studies. Dev Brain Res 73:107-113.

Thornhill RA (1970) Cell division in the olfactory epithelium of the lamprey, Lampreta fluviatilis. Z Zellforsch 109:147-157.
Verhaagen J, Oestreicher AB, Gispen WH, Margolis FL (1989) The expression of growth associated protein B50/GAP43 in the olfactory system of neonatal and adult rats. J Neurosci 9:683-691.

Walker DG, Breipohl W, Simon-Taha A, Lincoln D, Lobie PE, Aragon JG (1990) Cell dynamics and maturation within the olfactory epithelium proper of the mouse-a morphometric analysis, Chem Senses 15:741-753.

Weiler E, Farbman AI (1996) Mitral cell loss increases turnover of olfactory receptor cells. Chem Senses 21:686-687.

Zhang YP, Verhaagen J, Hamers FP, Gispen WH (1995) Elevated expression of B-50 (GAP-43)-mRNA in a subpopulation of olfactory bulb mitral cells following axotomy. Acta Physiol Sinica, $47: 38-44$. 